\title{
FLUCTUATIONS IN THE SELECTIVE VALUE OF CERTAIN PHENOTYPES IN THE POLYMORPHIC LAND SNAIL CEP IEA NEMORALIS (L.)
}

P. M. SHEPPARD

Department of Zoology and Comparative Anatomy, University of Oxford

\section{CONTENTS}

Received I8.x.50

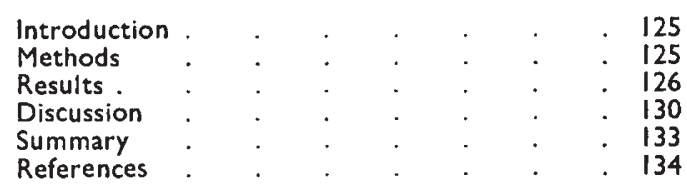

\section{INTRODUCTION}

VARIATION, within and between populations of many different species of animal and plant, has been quoted as being the result of genetic drift, on the lines suggested by Sewall Wright (e.g. 1940). One species which has been repeatedly referred to is the polymorphic land snail Cepea nemoralis (L.). However, Cain and Sheppard (1950) have shown that different colour and banding patterns have definite selective values, dependent upon the environment. Moreover, they showed that polymorphism in this species is normal and stable. They also showed that the ratio of the different genotypes within a breeding community is determined by the interplay of two kinds of selective advantage: one physiological and the other due to differential elimination by predators.

It is essential that these two components of selection should be separated if a more detailed knowledge of the relative importance of natural selection and genetic drift is to be obtained. The purpose of this paper is to give a preliminary report on the role played by the song thrush Turdus ericetorum Turton as an agent of natural selection.

\section{METHODS \\ (i) Collecting}

Every few days all the broken snail shells from thrush's " anvil" stones were collected from two localities in Wytham Woods : one in Marley Wood and the other, a mile and a quarter away, in Ten Acre Copse.

\section{(ii) Controls}

As a control 1358 snails, collected from other populations, were marked with quick-drying cellulose paint and scattered at random in the vicinity of the thrush "anvils" in Ten Acre Copse. 
The snails were marked by removing an area of the periostracum, from the body-whorl, in the vicinity of the umbilicus and replacing it with a thin layer of paint. It was found that if the periostracum was not scraped off some of the marks were lost. However, of 40 individuals marked in the correct way on 1 $3^{\text {th }}$ April none had lost their marks by 23 rd June. The part of the snail which is marked cannot be seen by predators, because it is on the ventral surface and is therefore concealed by the shell above and the surface on which the snail is resting below. (Plate I.)

Different colours were used in different sections of the locality in order that the area from which the thrushes were collecting should be known. The ratio of yellow to pink and brown shells in the marked population was $747: 611$. A sample of living marked snails was taken from Ten Acre Copse on 2oth May, and two samples of living unmarked snails were taken from Marley Wood on 14th April and 26th May; each snail was examined, marked with a small pencil mark and returned to the colony. To ensure that these samples were random ones, equal sub-divisions of the areas were searched for equal periods of time and all the snails that could be seen were collected, recorded and released. This method of sampling the population prevented the breeding-communities being disturbed by the removal and subsequent redistribution of snails, and at the same time it ensured that no snail was recorded twice.

\section{(iii) Recording}

The colour and banding patterns of the broken shells were recorded, using the system described by Cain and Sheppard (1950). Because many of the shells found on thrush " anvils" are broken into small pieces, it was decided, from the beginning, to use only those which had sufficient of the lip of the shell present to make it certain that each was derived from a different snail. All the shells from the Marley Wood " anvils" were recorded in this way except that, when the full band-formula could not be determined, the unknown bands were indicated by question marks. For example if all the bands on a yellow shell had been broken away, it was recorded as yellow ?????. If only bands one and two were lost it was recorded as yellow ?? 345 . In the Ten Acre Copse locality shells were also recorded as marked, or unmarked ; or, if the area which is painted was broken off, they were recorded as " marked area destroyed."

\section{RESULTS}

The results of collecting are given in tables 1,2 and 3 . If the percentage of yellow shells in the different samples is plotted against

\section{TABLE I}

Marley Wood

April 6th, 1950. Anvils cleared of all broken shells

\begin{tabular}{|c|c|c|c|c|}
\hline & $\begin{array}{l}\text { Pink and } \\
\text { brown }\end{array}$ & Yellow & Total & $\begin{array}{l}\text { Per cent. } \\
\text { yellow }\end{array}$ \\
\hline $\begin{array}{c}\text { April I Ith } \\
\text {, 23rd } \\
\text { May 30th } \\
\text { May 7th } \\
\text { ", 19th } \\
\text { 1922nd } \\
\text { ", 26th }\end{array}$ & $\begin{array}{r}4 \\
10 \\
21 \\
25 \\
16 \\
6 \\
12\end{array}$ & $\begin{array}{r}3 \\
7 \\
11 \\
9 \\
3 \\
1 \\
2\end{array}$ & $\begin{array}{r}7 \\
17 \\
32 \\
34 \\
19 \\
7 \\
14\end{array}$ & $\begin{array}{l}42 \cdot 9 \\
41 \cdot 2 \\
34 \cdot 4 \\
26 \cdot 5 \\
15 \cdot 8 \\
14 \cdot 3 \\
14 \cdot 3\end{array}$ \\
\hline
\end{tabular}

time (grouping them, in the way indicated in the tables, when the individual samples are small) it will be seen that there is an apparent 
TABLE 2

Ten Acre Copse, Unmarked Shells

April ist, 1950. Anvils cleared of all broken shells

\begin{tabular}{|c|c|c|c|c|}
\hline & $\begin{array}{c}\text { Pink and } \\
\text { brown }\end{array}$ & Yellow & Total & $\begin{array}{l}\text { Per cent. } \\
\text { yellow }\end{array}$ \\
\hline $\begin{array}{c}\text { April 19th } \\
\Rightarrow \quad 2 \text { 1st } \\
", 22 n d \\
", 25 \text { th } \\
", 26 \text { th }\end{array}$ & $\begin{array}{l}0 \\
2 \\
1 \\
2 \\
2\end{array}$ & $\begin{array}{l}1 \\
0 \\
1 \\
1 \\
2\end{array}$ & $\left.\begin{array}{l}1 \\
2 \\
2 \\
3 \\
4\end{array}\right\}$ & $4^{I} \cdot 7$ \\
\hline $\begin{array}{cc}\text { May } & \text { 28th } \\
\text { 1st } \\
\text {," } & \text { 2nd }\end{array}$ & $\begin{array}{l}1 \\
2 \\
4\end{array}$ & $\begin{array}{l}0 \\
1 \\
\text { I }\end{array}$ & $\left.\begin{array}{l}x \\
3 \\
5\end{array}\right\}$ & $22 \cdot 2$ \\
\hline $\begin{array}{ll}" & 4^{\text {th }} \\
" & 5^{\text {th }} \\
" & 8 \text { th }\end{array}$ & $\begin{array}{l}2 \\
3 \\
3\end{array}$ & $\begin{array}{l}0 \\
0 \\
1\end{array}$ & $\left.\begin{array}{l}2 \\
3 \\
4\end{array}\right\}$ & $I I \cdot I$ \\
\hline $\begin{array}{ll}\Rightarrow & \text { 11th } \\
\#, & 12 \text { th } \\
, & \text { 16th }\end{array}$ & $\begin{array}{l}3 \\
2 \\
2\end{array}$ & $\begin{array}{l}1 \\
0 \\
0\end{array}$ & $\left.\begin{array}{l}4 \\
2 \\
2\end{array}\right\}$ & 12.5 \\
\hline $\begin{array}{ll}\# & \text { 17th } \\
\# & 20 \text { th } \\
" & 22 \text { nd }\end{array}$ & $\begin{array}{l}1 \\
4 \\
2\end{array}$ & $\begin{array}{l}\mathbf{0} \\
0 \\
0\end{array}$ & $\left.\begin{array}{l}1 \\
4 \\
2\end{array}\right\}$ & 0 \\
\hline $\begin{array}{cc}\text { ", 28th } \\
\text { June } & \text { 3oth } \\
\text { Jue } & 3^{\text {th }} \\
\text {, } & 5^{\text {th }}\end{array}$ & $\begin{array}{r}2 \\
1 \\
2 \\
11\end{array}$ & $\begin{array}{l}0 \\
1 \\
0 \\
1\end{array}$ & $\left.\begin{array}{r}2 \\
2 \\
2 \\
12\end{array}\right\}$ & $I I \cdot I$ \\
\hline
\end{tabular}

TABLE 3

Ten Acre Copse, marked shells

April 26th, 1950. Marked snails released

\begin{tabular}{|c|c|c|c|c|}
\hline & $\begin{array}{c}\text { Pink and } \\
\text { brown }\end{array}$ & Yellow & Total & $\begin{array}{l}\text { Per cent. } \\
\text { yellow }\end{array}$ \\
\hline $\begin{array}{cc}\text { April } & 28 \text { th } \\
\text { May } & \text { 1st } \\
\Rightarrow & \text { 2nd }\end{array}$ & $\begin{array}{l}0 \\
0 \\
1\end{array}$ & $\begin{array}{l}2 \\
1 \\
1\end{array}$ & $\left.\begin{array}{l}2 \\
x \\
2\end{array}\right\}$ & $80 \cdot 0$ \\
\hline $\begin{array}{ll}\prime & 5^{\text {th }} \\
\Rightarrow & 8 \text { th }\end{array}$ & $\begin{array}{l}1 \\
3\end{array}$ & $\begin{array}{l}3 \\
9\end{array}$ & $\left.\begin{array}{r}4 \\
32\end{array}\right\}$ & $75 \cdot 0$ \\
\hline $\begin{array}{ll}\# & \text { 1rth } \\
\#, & 12 \text { th } \\
\#, & \text { 16th }\end{array}$ & $\begin{array}{l}0 \\
7 \\
0\end{array}$ & $\begin{array}{l}\mathrm{I} \\
4 \\
\mathrm{I}\end{array}$ & $\left.\begin{array}{c}x \\
x \\
x\end{array}\right\}$ & $46 \cdot 2$ \\
\hline $\begin{array}{ll}\# & 17^{\text {th }} \\
\# & 20 \text { th } \\
\# & 22 \text { nd }\end{array}$ & $\begin{array}{l}0 \\
1 \\
1\end{array}$ & $\begin{array}{l}1 \\
0 \\
1\end{array}$ & $\left.\begin{array}{l}x \\
x \\
2\end{array}\right\}$ & $50 \cdot 0$ \\
\hline $\begin{array}{cc}\text { June } & 3^{\text {oth }} \\
3^{\text {rd }} & 5^{\text {th }}\end{array}$ & $\begin{array}{l}0 \\
2 \\
3\end{array}$ & $\begin{array}{l}2 \\
1 \\
0\end{array}$ & $\left.\begin{array}{l}2 \\
3 \\
3\end{array}\right\}$ & $37 \cdot 5$ \\
\hline
\end{tabular}


decrease in the percentage of yellow shells with time. (In the graph the percentages of yellow shells have been transformed into angular measure) (figs. I and 2). Moreover, the slope of the graph obtained from the Marley Wood samples (fig. I) is not so steep as those in the second graph (fig. 2).

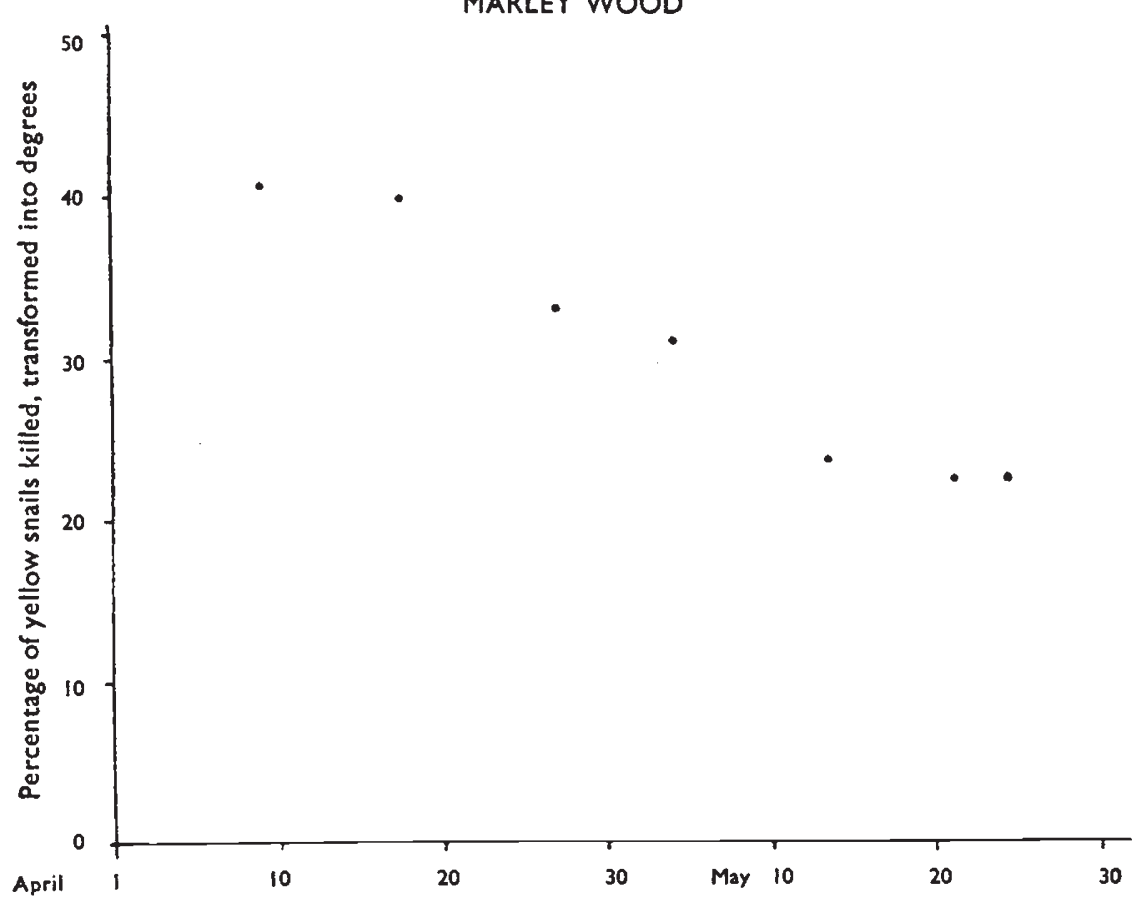

FIG. I. - The graph shows the percentage of yellow snails killed on the Marley Wood "Anvils," plotted against time in days. The percentage of yellow snails has been transformed into angular measure.

The results of collecting random samples of living snails in the vicinity of thrush "anvils" in Marley Wood and Ten Acre Copse are given in table 4 .

TABLE 4

Living snails

\begin{tabular}{|c|c|c|c|c|}
\hline Date & Locality & Yellow & $\begin{array}{l}\text { Pink and } \\
\text { brown }\end{array}$ & $\begin{array}{c}\text { Per cent. } \\
\text { yellow }\end{array}$ \\
\hline $\begin{array}{l}\text { April i4th } \\
\text {,, 26th } \\
\text { May 2oth } \\
\text {," 20th } \\
\text {," 26th }\end{array}$ & $\begin{array}{l}\text { Marley Wood } \\
\text { Ten Acre Copse (Marked snails } \\
\quad \text { released). } \\
\text { Ten Acre Copse (Unmarked shells) } \\
\text { Ten Acre Copse (Marked shells) } \\
\text { Marley Wood } \\
\text { M. }\end{array}$ & $\begin{array}{r}80 \\
747 \\
2 \\
19 \\
57\end{array}$ & $\begin{array}{r}250 \\
6 \text { I I } \\
5 \\
\text { I } 3 \\
147\end{array}$ & $\begin{array}{l}24 \cdot 2 \\
55 \cdot 0 \\
28 \cdot 6 \\
59 \cdot 4 \\
27 \cdot 9\end{array}$ \\
\hline
\end{tabular}

Both the Marley Wood and Ten Acre Copse localities are clearings in the wood and both have Bracken (Pteridium aquilinum (L.) Kuhn.), 
Willow-herb (Epilobium sp.), Dog's Mercury (Mercurialis perennis L.), Brambles (Rubus sp.), grasses and other herbs, growing in them. However, the Marley Wood area is more open, with less Dog's

TEN ACRE COPSE

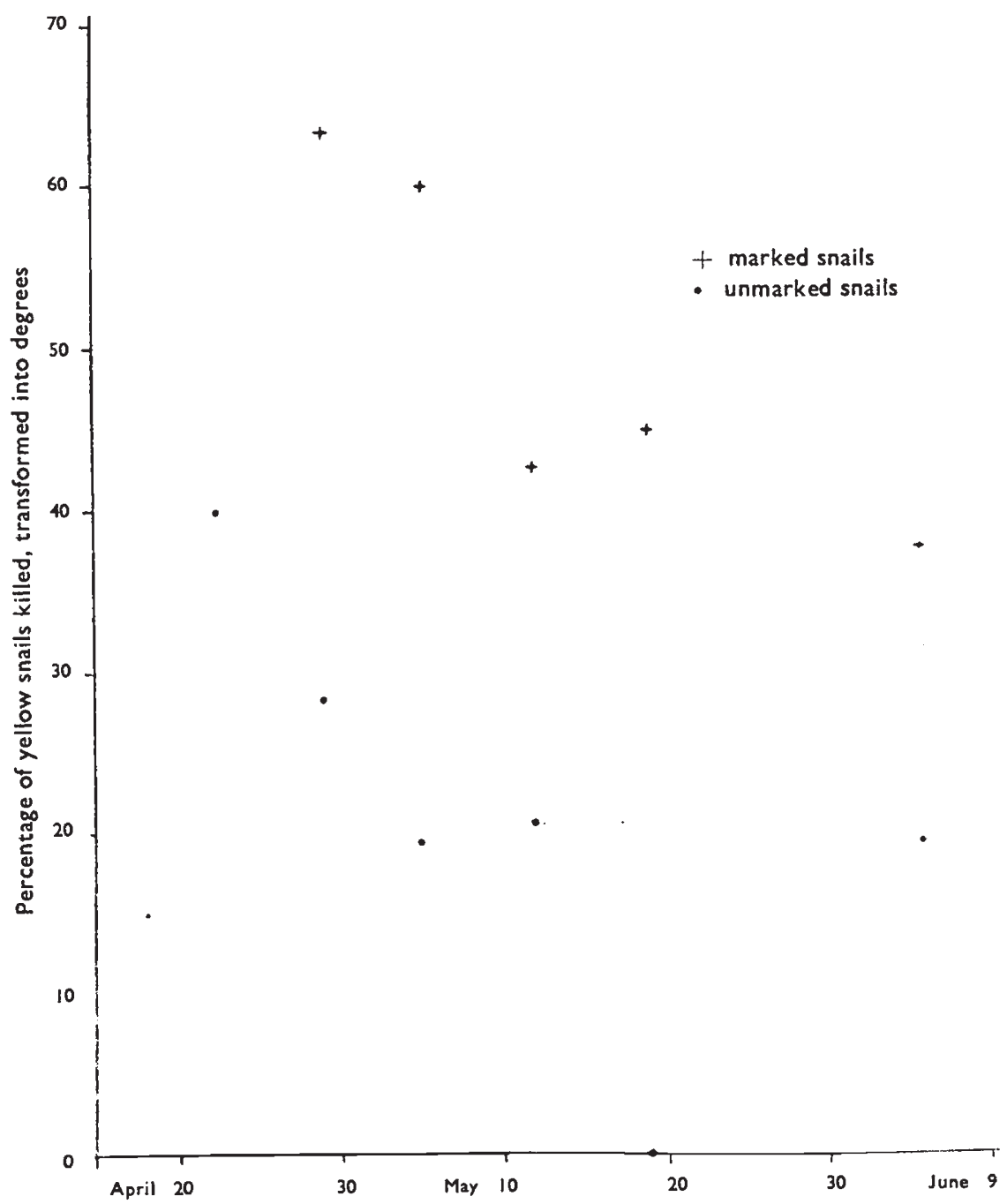

Fig. 2.-The graph shows the percentage of yellow snails, from the wild and the marked population, which were killed by thrushes on the Ten Acre Copse "Anvils." The samples are grouped in the way indicated in tables 2 and 3 , when the individual samples are small.

Mercury and with more grass. It was as green or greener than Ten Acre Copse at the beginning of the season but showed a less striking increase in greenness from the beginning of April until the middle of May, chiefly because in Ten Acre Copse there is an abundance of Dog's Mercury, which came into leaf during this period (plate II). 


\section{DISCUSSION}

The slope of the graphs (figs. I and 2) indicate that there is a reduction in the percentage of yellow snails destroyed by thrushes as the season progresses. It is therefore important to discover if the regression is significant.

A logit analysis of the Marley Wood and Ten Acre Copse data was carried out and the last cycle of the calculations for Marley Wood is tabulated below. However, in Ten Acre Copse there was a marked and a wild population, with different ratios of phenotypes, living in the same area. Therefore the two sets of data were analysed together, it being assumed that the two regression lines were parallel. It was possible, during the calculations, to show that there was no evidence that this was not true $(\mathbf{P}>0.5)$. Because of the method of calculation it was also possible to consider the marked population separately. This is important because only in the marked population was the area from which the thrushes were collecting snails accurately known.

Marley Wood

\begin{tabular}{|c|c|c|c|c|c|c|}
\hline April & $\begin{array}{l}\text { Provisional } \\
\text { logit }\end{array}$ & $\mathbf{R}$ & W & WX & $\begin{array}{c}\text { Working } \\
\text { logit }\end{array}$ & WY \\
\hline \multirow[t]{2}{*}{$\begin{array}{l}9 \\
17 \cdot 5 \\
27 \\
34 \\
43 \cdot 5 \\
51 \\
54 \cdot 5\end{array}$} & $\begin{array}{l}0.01488 \\
0.18733 \\
0.38007 \\
0.52208 \\
0.71482 \\
0.86697 \\
0.93798\end{array}$ & $\begin{array}{l}0.0149 \\
0.1851 \\
0.3628 \\
0.4793 \\
0.6137 \\
0.6999 \\
0.7343\end{array}$ & $\begin{array}{r}6 \cdot 998 \\
16 \cdot 417 \\
27 \cdot 776 \\
26 \cdot 189 \\
11 \cdot 844 \\
3 \cdot 571 \\
6 \cdot 451\end{array}$ & $\begin{array}{r}62 \cdot 98 \\
287 \cdot 30 \\
749 \cdot 95 \\
890 \cdot 43 \\
515 \cdot 21 \\
182 \cdot 12 \\
35^{1} \cdot 58\end{array}$ & $\begin{array}{l}0 \cdot 14287 \\
0 \cdot 17839 \\
0 \cdot 32155 \\
0 \cdot 51077 \\
0 \cdot 82793 \\
0 \cdot 89517 \\
0 \cdot 89455\end{array}$ & $\begin{array}{r}0.9998 \\
2 \cdot 9286 \\
8.9314 \\
13.3766 \\
9.8060 \\
3.19 \hat{c} 7 \\
5.7707\end{array}$ \\
\hline & & & $99 \cdot 246$ & 3039.57 & & $45^{\circ} \cdot 0098$ \\
\hline \multicolumn{4}{|c|}{$\begin{array}{ll}\bar{x}=30 \cdot 62662 & \mathrm{~S}\{x(w x)\}-\bar{x} \mathrm{~S}(w x)= \\
\bar{y}=0 \cdot 4535175 & \mathrm{~S}\{y(w x)\}-\bar{y} \mathrm{~S}(w x)= \\
b=0.02029205 \mathrm{~S}\{y(w y)\}-y \mathrm{~S}(w y)=\end{array}$} & $\begin{array}{l}386 \cdot 95 \\
81 \cdot 7946 \\
6 \cdot 099^{2} \mathrm{re}\end{array}$ & \multicolumn{2}{|c|}{ 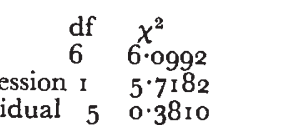 } \\
\hline
\end{tabular}

It will be seen that the Marley Wood data gives a significant regression with $\mathrm{P}<0 \cdot 02$. The shells collected from Ten Acre Copse also show a regression with $\mathrm{P}<0 \cdot 0 \mathrm{r}$, and the $\chi^{2}$ for parallelism gives no evidence that the two regression lines for Marley Wood and Ten Acre Copse are not parallel, $\mathrm{P}>0 \cdot 2$. The data for the marked population, when examined separately, also shows evidence of a regression $\mathrm{P}<0 \cdot 05$.

It has been pointed out by Diver (1940) and Cain and Sheppard (1950) that the distribution of colour and banding patterns within a colony of $C$. nemoralis may vary slightly from area to area. It is therefore possible that the observed regressions are the result of thrushes changing their feeding grounds as the season progresses and the ecological situation changes. However, it must be assumed that the new areas, from which the thrushes are feeding later in the season, 
both have lower proportions of yellow snails than those previously hunted and also that the thrushes are carrying snails quite appreciable distances. This is unlikely because "anvils" 30 yards outside the area in which marked snails were released, have never had any of these marked individuals broken on them. Moreover, snails bearing a distinctive mark were released in the vicinity of these stones and although they were found on them on subsequent days they were never found on those used in the main experiment. It seems that thrushes in Ten Acre Copse were never carrying snails more than 20 yards and usually less.

There is additional evidence that the thrushes were not changing the area over which they were collecting snails, for not only is the regression calculated from samples of marked individuals, which clearly can only belong to one population, a significant regression, although scarcely so, but also if the ratio of marked to unmarked shells is examined (table 5) there is no evidence of the regression which

TABLE 5

Ten Acre Copse, marked and unmarked shells

\begin{tabular}{|c|c|c|c|}
\hline Date & Marked & Unmarked & Total \\
\hline April 28th & 2 & I & 3 \\
\hline May ist & I & 3 & 4 \\
\hline ," 2nd & 2 & 5 & 7 \\
\hline , $\quad 4^{\text {th }}$ & 0 & 2 & 2 \\
\hline , $5^{\text {th }}$ & 4 & 3 & 7 \\
\hline , 8th & 12 & + & 16 \\
\hline , IIth & I & 4 & 5 \\
\hline "I2th & II & 2 & 13 \\
\hline "I6th & I & 2 & 3 \\
\hline,$\quad$ I 7 th & I & I & 2 \\
\hline 20 th & I & 4 & 5 \\
\hline 22nd & 2 & 2 & 4 \\
\hline,$\quad$ 28th & o & 2 & 2 \\
\hline$\Rightarrow \quad 3$ oth & 2 & 2 & 4 \\
\hline June $3^{\text {rd }}$ & 3 & 2 & 5 \\
\hline,$\quad 5^{\text {th }}$ & 3 & 12 & 15 \\
\hline
\end{tabular}

would be expected if the thrushes were altering their feeding area. There is not even any evidence that the ratio varies from day to day. Thus the hypothesis that the regression is the result of a change in the feeding habits of the thrushes can be rejected.

If the thrushes are not altering their collecting grounds, then either the proportion of the two-colour classes in the colony or the propertion of them killed by thrushes is changing. There is no evidence, from samples of living snails, taken from Ten Acre Copse and Marley Wood, that the percentage of the yellow phenotype is decreasing in either population (table 4). In fact both show a slight increase although this is not statistically significant. Cain and Sheppard (1950) demonstrated that the selective value of yellow increases with an increase in the greenness of the background at 
ground level. In the two areas under consideration. the greenness of the background increased markedly between the middle of April and the middle of May. It is not unreasonable to suppose that the observed regressions are caused by real changes in the selective advantage of the yellow phenotype, as a result of alterations in the background colour. Moreover, the percentage of yellow snails in the marked population is known and the proportion in the Marley Wood colony can be estimated from samples of living snails (table 4). Thus, it is possible to say not only that the selective advantage of yellow was changing but also that it was at a disadvantage during most of April, becoming neutral in value some time in late April or early May, and that by the middle of May it was actually at an advantage.

The actual selective value of yellow cannot be estimated until more information is available about the size of the population from which the thrushes are collecting, the final amount of differential elimination during the whole life of the snail, including the immature stages which are probably eaten whole, and the physiological selection. However, it is certain that the selective value will alter markedly from season to season, year to year and locality to locality, as the result of slight changes in the background colour in different seasons and years as well as differences in the intensity of predation and other changes in the ecology of the colony. These are quite sufficient to account for all the observed differences between breeding communities.

The selective value of yellow may be exceedingly small in the two localities which have been discussed, for it must be remembered that the differential elimination of snails which have been killed has been studied and not changes in the gene frequency resulting from this elimination, although this can be obtained from the marked population, over the period of the observations.

Alterations in the selective value of certain genes and gene combinations have been demonstrated on several occasions. Ford (1937) suggested that the spread of the " melanic" form of some Lepidoptera, in industrial neighbourhoods, is the result of a change in the selective value of a genotype, which has previously been kept at a low density by selection, and later demonstrated the type of differential viability which had been envisaged (1940). Timofeeff-Ressovsky (I940) showed that the black forms of Adalia bipunctata L. are at a disadvantage during the winter and at an advantage during the summer. Polymorphism in that species is probably caused by the heterozygotes being at an advantage compared with the homozygotes, but with the relative selective advantages of the different genotypes varying from season to season and year to year. More recently Fisher and Ford (1947) have shown that a certain gene in a population of the moth Panaxia dominula (L) is subject to selection, and that it was at a considerable advantage between 1929 and 1939 and that since then it has usually been at a disadvantage. Dobzhansky (r943, I948), Carson and Stalker (r949), Dubinin and Tiniakov (1945) and others 
have shown large changes in the selective advantage of certain genotypes in several species of Drosophila.

If the magnitude of the changes in selection are as great in genes having small selective values as those already discussed, then such changes will be of considerable evolutionary importance, particularly in populations which are restricted to a small area. In breedingcommunities occupying large areas, changes in the environment which alter the selective advantage of certain genes in one place will tend to be counter balanced by opposite changes in other areas. However, in populations living in a restricted area changes in the environment may well cause certain genes to be lost and others to become fixed in the colony. In fact changes in the environment altering selection pressures can result in changes identical with those ascribed to drift, and these will be of sufficient magnitude to be able to override any drift effect, except in the smallest populations. Moreover, such changes in the environment may well be of considerable importance for unlike drift, their effect is not confined to numerically small populations which will not be as variable as larger ones, but only to breeding-communities inhabiting a restricted area.

Changes in selective values have been demonstrated in a high proportion of recent investigations into natural selection. Moreover, environments are not constant, so that the relative selective values of any pair of allelomorphs, which regulate the relationship between the organism and its environment, will fluctuate. In view of these facts, it is possible that such fluctuations are the normal situation in wild populations, and constant selective values over long periods may be rare.

\section{SUMMARY}

I. All the broken shells from thrush's "anvils" in two localities, Marley Wood and Ten Acre Copse, were collected every few days.

2. $135^{8}$ snails, which had been marked with a permanent mark, on a part of the shell which could not be seen by predators, were released in the Ten Acre Copse area.

3. Random samples of living snails were collected from the two areas on several occasions.

4. The colour and banding patterns of the broken shells were recorded, using a modification of the method described by Cain and Sheppard (I950).

5. It was observed that the percentage of yellow snails killed by thrushes decreased from the middle of April to the middle of May and that the background colour in the two areas became greener during this period.

6. It was shown that not only was there a real decrease in the percentage of yellow snails killed as the season progressed, but also that there was no evidence that the rate of change was different in the two localities.

7. There was evidence that this result was not due to thrushes 


\section{Plate I}

a. Two living snails, one banded the other not banded, showing the position of the cellulose paint mark.

b. A living marked snail, in the position in which it was found in Ten Acre Copse, three weeks after it had been released. Note that the paint mark is not visible in the living snail until it is turned over.

c. One of the "a nvils" in Ten Acre Copse. 


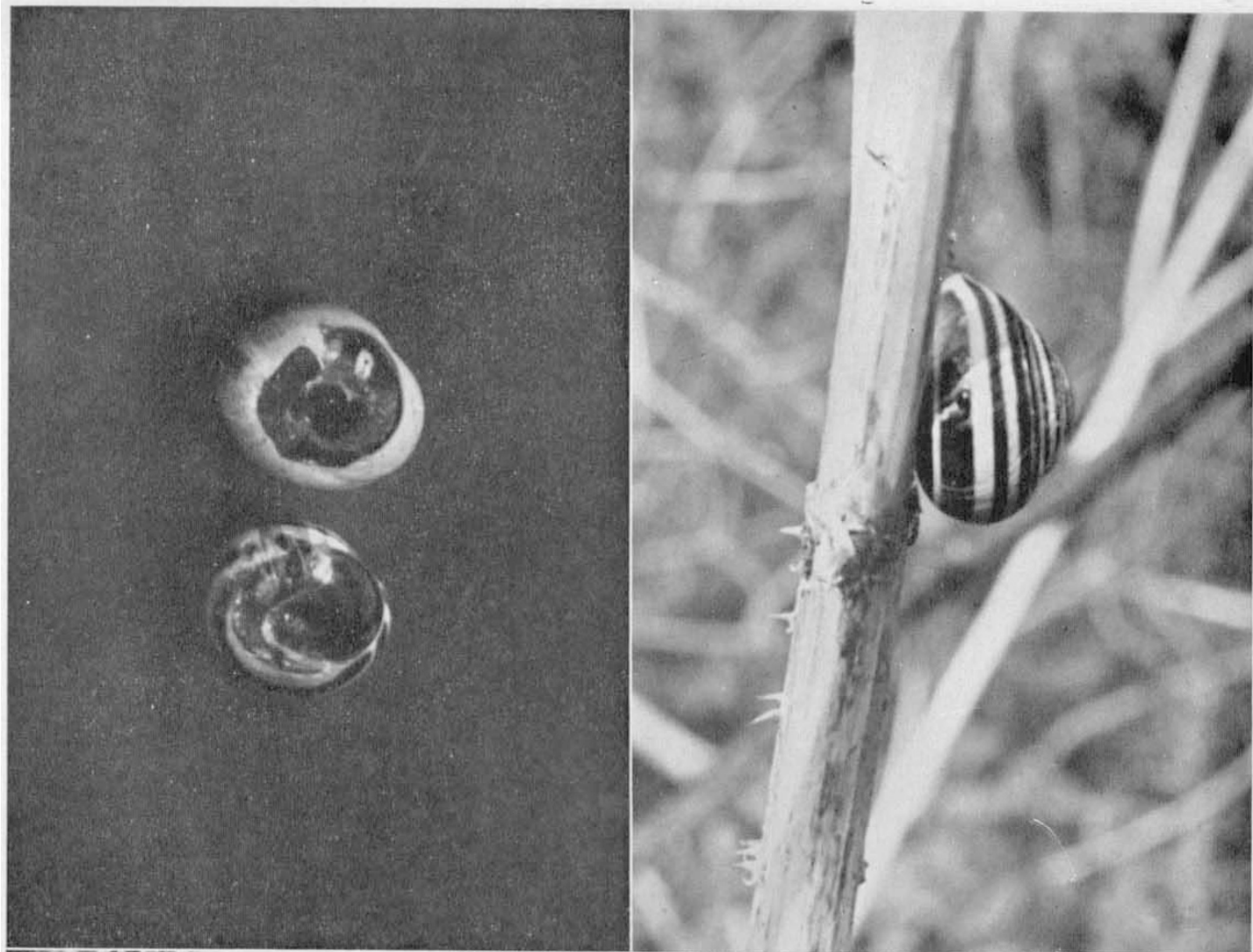

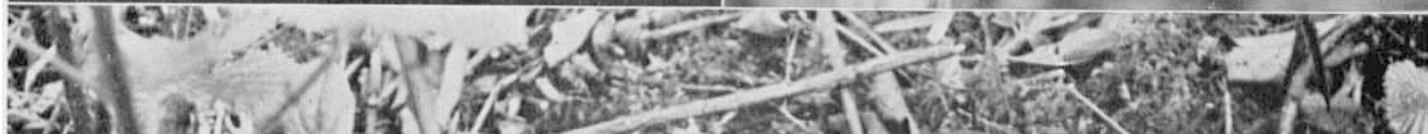

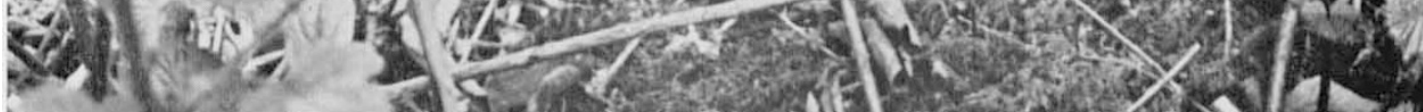

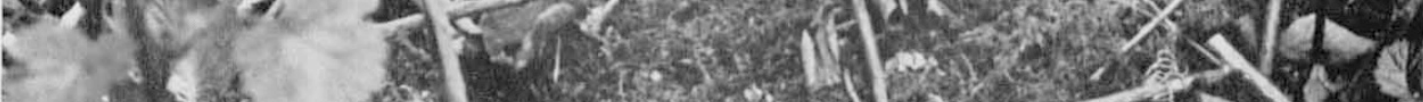

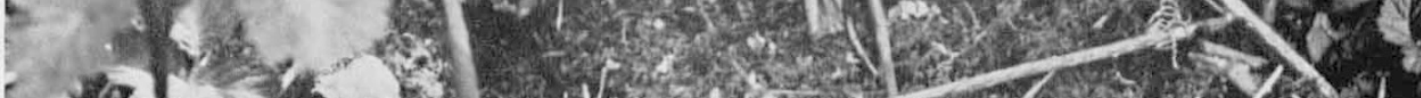
(n) 1 , $k+1,1$

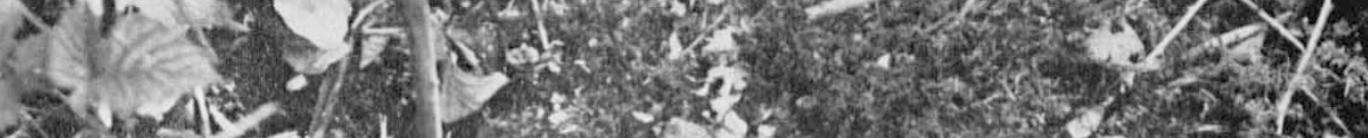
(5)

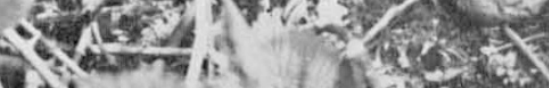

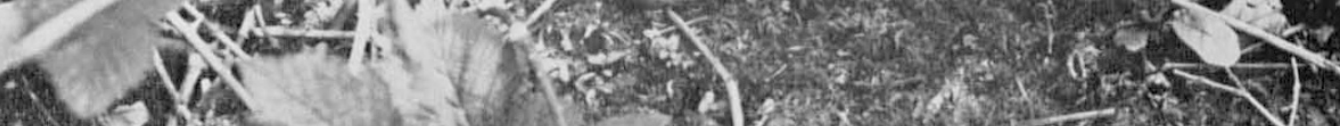

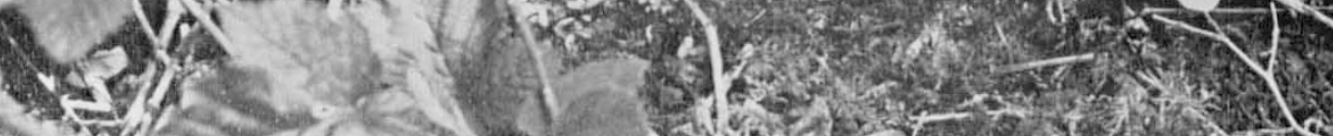

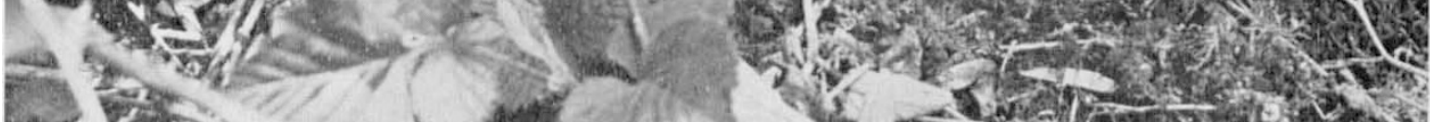
- The lk

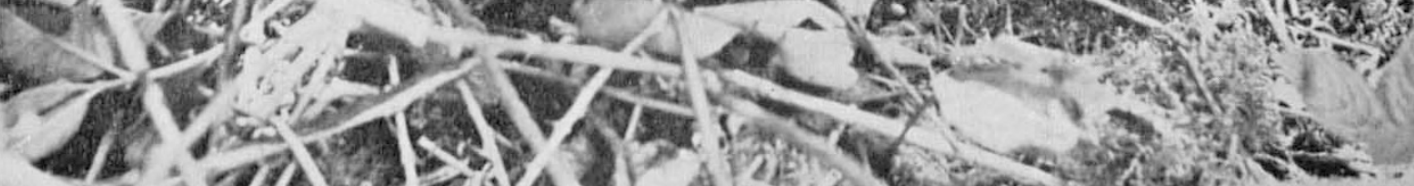

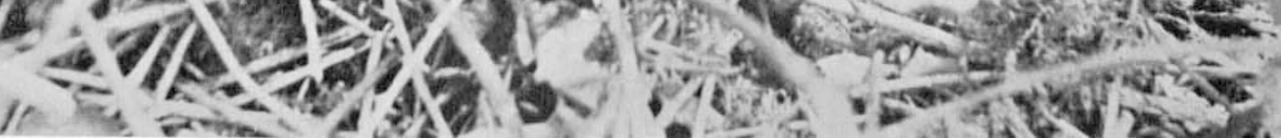




\section{Plate II}

a. The area in Marley Wood in which the thrushes were collecting snails.

$b$. The area in Ten Acre Copse in which the thrushes were collecting snails. 


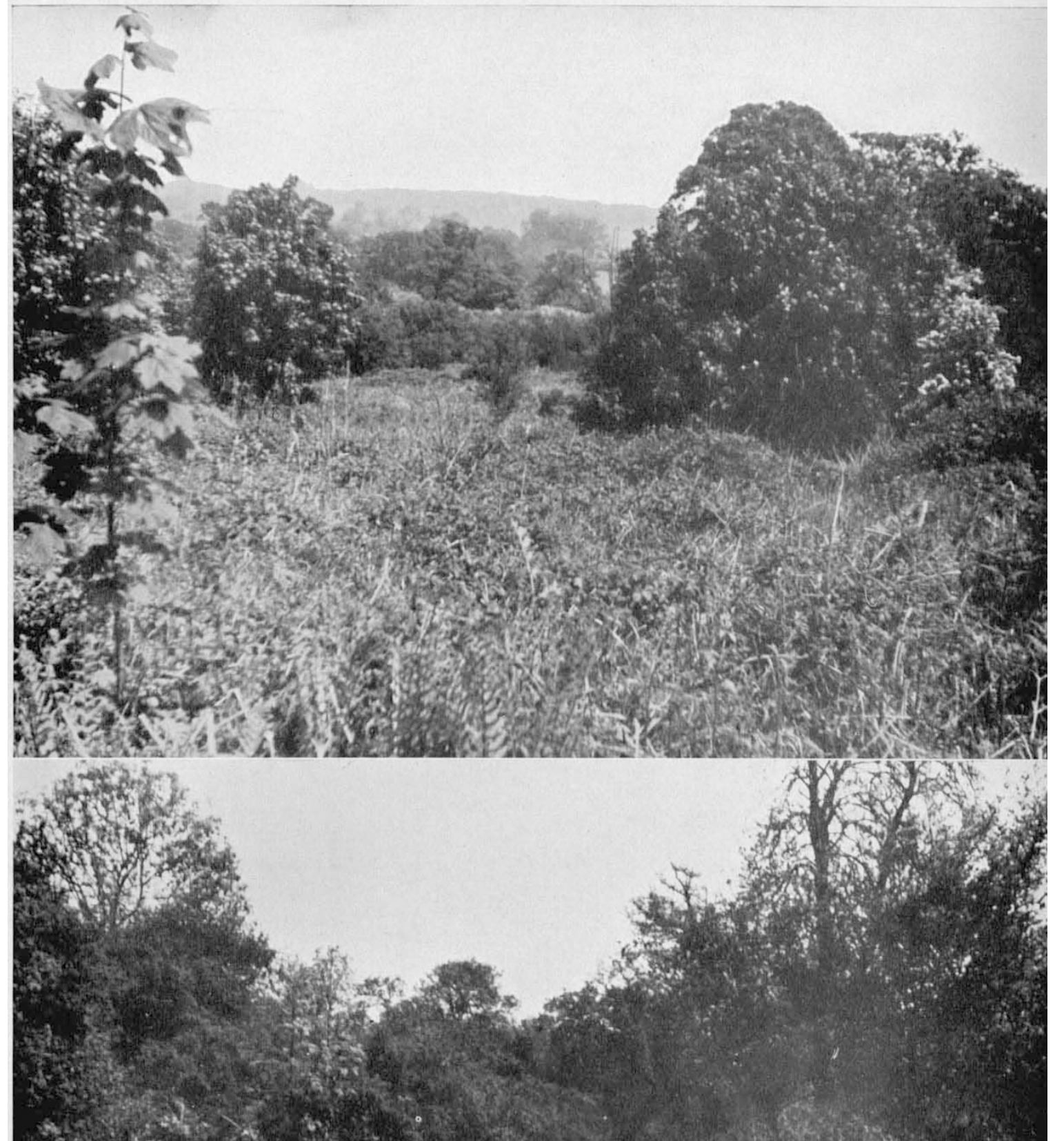

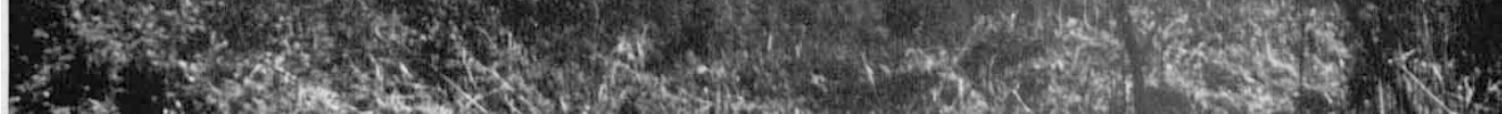
W

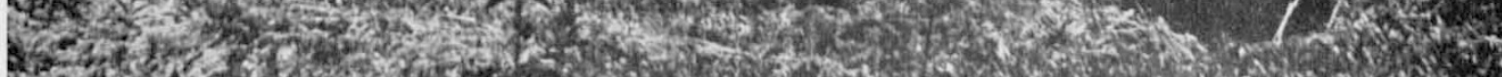
(1) H. W.

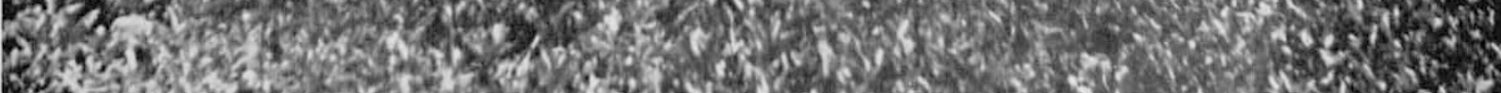
4. 
changing their feeding grounds or to the percentage of yellow snails in both Marley Wood and the marked population decreasing between the middle of April and the middle of May.

8. The most probable hypothesis to explain the significant regressions is that the selective value of the yellow phenotype varied with changes in the background colour. Yellow was at a disadvantage in the middle of April, when the background at ground level was relatively brown; it became neutral in value at some time in late April or early May and by the middle of May it was at an advantage.

9. Changes in the selective value of certain genotypes have been demonstrated on several occasions. It is suggested that if these are of common occurrence, they will cause fluctuations in the ratio of different genotypes in wild populations. These fluctuations will be most marked in populations inhabiting a restricted area. Moreover, they will have the same evolutionary consequences as genetic drift but, unlike drift, they will be controlled by selection, and will not be confined to numerically small populations.

Io. Selective values may normally fluctuate in wild populations, and constant values over long periods may well be exceptional.

Acknowledgments.-m-I am indebted to Mr P. H. T. Hartley for invaluable advice on the position of the Thrush " anvils" in Wytham Woods as well as for the many samples of snails he collected in the Ten Acre Copse Area. I am also indebted to Professor R. A. Fisher and Mr M. R. Samford for statistical advice, to Dr E. B. Ford who read this paper in manuscript and to Mr S. E. Smith who took the photographs for the Plates.

I am indebted to the Department of Scientific and Industrial Research for a maintenance grant during the whole of this investigation.

\section{REFERENCES}

GAIN, A. J., AND SHeppard, P. M. 1950. Selection in the polymorphic land snail Cepea nemoralis (L.). Heredity, 4, 275-294.

GARSON, H. L., AND STALKER, H. D. 1949. Seasonal variation in gene arrangement frequencies over a three-year period in Drosophila robusta. Sturtevant. Evolution, $3,322-329$.

DIVER, c. 1940. The problem of closely related species living in the same area. In The New Systematics, ed. Huxley. Oxford.

DOBZHANSKY, T. 1943. Genetics of natural populations. IX. Temporal changes in the composition of populations of Drosophila pseudoobscura. Genetics, 28, 162-186. Dobzhansky, т. 1948. Genetics of natural populations. XVI. Altitudinal and seasonal changes produced by natural selection in certain populations of Drosophila pseudoobscura and Drosophila persimilis. Genetics, 33, $158-176$.

Dubinin, N. P., AND tiniakov, G. G. 1945. Seasonal cycles and the concentration of inversions in populations of Drosophila funebris. Amer. Nat., 79, 570-572.

FISHER, R. A., AND FORD, E. B. 1947. The spread of a gene in natural conditions in a colony of the moth Panaxia dominula L. Heredity, $x$, I $43-174$.

FORD, E. B. 1937. Problems of heredity in the Lepidoptera. Biol. Rev., 12, 461-503. FORD, E. B. 1940. Genetic Research in the Lepidoptera. Ann. Eug., 1o, 227-252. timofeeff-Ressovsky, N. W. 1940. Zur Analyse des Polymorphismus bei Adalia bipunctata. Biol. Zbl., 6o, i $30-137$.

WRIGHT, s. 1940. The statistical consequences of Mendelian heredity in relation to speciation. In The New Systematics, ed. Huxley. London: Oxford. 